\title{
Er Høyesterett en konstitusjonsdomstol?
}

Professor, dr. juris Eivind Smith

Universitetet i Oslo

Eivind Smith er professor i offentlig rett ved Universitetet i Oslo. Han har et stort antall publikasjoner på flere språk i norsk og komparativ stats- og forvaltningsrett, har ledet flere offentlige utvalg, og har omfattende internasjonal erfaring.

De høyeste domstolene i Norden har blitt omtalt som konstitusjonsdomstoler. Artikkelen setter vår egen høyesterett inn i et nordisk perspektiv med særlig vekt på oppgaver av konstitusjonell karakter, særlig domstolskontroll med lover. Etter noen ord om grunnloven $\S$ 89 gjennomgår den noen hovedtrekk av Høyesteretts rolle i dag og domstolens vektlegging av «rettsutvikling», dvs. rettsskapende virksomhet av grunnleggende politisk karakter. Sammenligning med slike egentlige konstitusjonsdomstoler som vi finner $i$ de fleste land $i$ Europa, viser så store ulikheter at betegnelsen passer dårlig hos oss. Dette skyldes blant annet at dommere med konstitusjonelle oppgaver $\mathrm{i}$ andre land typisk blir utpekt gjennom prosesser med åpent, men balanserte, politiske innslag. Hvorfor bør rekrutteringen akkurat hos oss skje ut fra faglig-juridisk kriterier alene?

\section{Innledning ${ }^{1}$}

De siste årene har Høyesterett stadig oftere blitt betegnet som «konstitusjonsdomstol». Den første til å bruke en slik terminologi var trolig høyesterettsdommer Arnfinn Bårdsen («De nordiske høyesterettene som konstitusjonsdomstoler», se nærmere i punkt 7). Ordvalget kan tjene som innfallsport til den økende debatten om Høyesteretts konstitusjonelle - og dermed politiske - rolle.

Bårdsens innlegg kom i et foredrag på et nordisk seminar for høyesterettsdommere. Dette gir i seg selv grunn til å betrakte vår egen høyeste domstol i et nordisk perspektiv (punkt 2): Dette vil blant annet vise at betegnelsen i alle fall ikke passer på andre høyesteretter enn vår egen.

Det arbeidsområdet som særlig peker seg ut hvis man vil drøfte Høyesteretts rolle som «konstitusjonsdomstol», er domstolskontrollen med lover mv. (punkt 3-5). Det er også her

\footnotetext{
${ }^{1}$ En tidligere versjon av denne artikkelen er publisert i Dahl m.fl. (red.), Festskrift til Jens Peter Christensen, Jurist- og Økonomforbundets Forlag, København 2016 s. 681-702.
} 
at spørsmålet om Høyesteretts «rettsutviklende» rolle - en rolle retten et stykke på vei selv har «funnet på» - kommer på spissen (punkt 6-7).

Vi har nå grunnlag for å drøfte om betegnelsen «konstitusjonsdomstol» er treffende. Dette må skje ved å holde vår egen Høyesterett opp mot typiske trekk ved domstoler i mange land som er etablert med særlig sikte på å arbeide med konstitusjonelle spørsmål (punkt 8-9). Et sentralt element i slike systemer er at domstolskontrollen er abstrakt: Den gjelder lovbestemmelsen som sådan. Dette står i motsetning til domstolskontrollen slik den har vokst frem hos oss: Den gjelder lovens anvendelse i den enkelte sak (konkret kontroll). Også dommerrekrutteringen er annerledes, ikke minst fordi den i de spesialiserte konstitusjonsdomstolene skjer helt eller delvis etter åpent politiske kriterier.

Den tyske forbundsforfatningsdomstolen er vel den konstitusjonsdomstolen i Europa som er best kjent hos oss. Den spiller en vesentlig større rolle i statslivet i Tyskland enn den føderale høyesteretten i USA.

Avslutningsvis bindes det hele sammen gjennom noen normative betraktninger om det å dyrke en politisk - i betydningen rettsskapende - rolle for en domstol besatt etter fagligjuridiske kriterier (punkt 10): Hvorfor skulle kandidatenes samfunnssyn, ikke minst synet på nettopp Høyesteretts rettsskapende rolle, være irrelevant ved besettelsen av dommerembeter?

\section{Norden som bakteppe}

Som hjelp i arbeidet med å skape oversikt og forståelse av vårt eget, kan rettssystemene i Norden deles i to grupper: Den vestnordiske, med København (før tapet av Norge og Island) som historisk utgangspunkt, og den østnordiske, med Stockholm ( $\varnothing \varnothing r$ tapet av Finland) i en tilsvarende posisjon. De tre (vest) eller to (øst) rettssystemene som inngår i disse gruppene, er selvsagt ikke identiske. Likevel er inndelingen egnet til å identifisere ganske mange trekk der de to gruppene skiller lag.

Et lett synlig særtrekk er eksistensen av særskilte forvaltningsdomstoler i $\varnothing$ st, noe vi ikke finner i vest. Men selv om åpningen for å innføre egne forvaltningsdomstoler (riktignok underlagt den felles $\mathrm{H} \varnothing$ jesteret) som følger $\S 63$ stk. 2 i Danmarks grundlov aldri har vært 
benyttet, har vi også i Vest-Norden etter hvert fått en rekke forvaltningsorganer som i praksis fungerer som forvaltningsdomstoler på omtrent samme måte som dem vi finner i øst (og i store deler av Europa for $\varnothing$ vrig). Formelt er det tale om forvaltningsorganer med betydelig, lovfestet uavhengighet og med en organisering som ligger de egentlige forvaltningsdomstolene nær. Og selv om deres avgjørelser kan prøves i de ordinære domstolene, er det også i Vest-Norden slik at det vesentlige av «rettspleien» i forvaltningsretten finner sted i slike de facto-forvaltningsdomstoler (når den ordinære forvaltningens egne avgjørelser og uttalelser ikke strekker til). Men både formelt og praktisk har ulikhetene mellom «øst» og «vest» på dette punkt likevel store konsekvenser.

Siden den finske grundlagen trådte i kraft i 2000 har $\varnothing$ st- og Vest-Norden derimot funnet sammen i den forstand at en hvilken som helst domstol (i øst: av begge typer) ikke bare har kompetanse til å prøve privat-, forvaltnings-, strafferettslige osv. spørsmål, men også spørsmål av konstitusjonell karakter som kommer opp. ${ }^{2}$

Dermed har altså de øverste rettsinstansene i hvert land kompetanse på alle rettsområder; dette gjelder både den ene høyesterett i hvert land som vi finner i vest, og de to øverste instansene vi finner i øst. De kan prøve om den lovgivende eller ut $\varnothing$ vende makt (eller lavere domstoler) har holdt seg innenfor de grenser som følger av landets konstitusjon. Og siden det ikke er andre prosedyrer for rekruttering av dommere til å behandle saker av konstitusjonell karakter, enn slike som gjelder for dommerrekruttering generelt, er det samme dommere som behandler alle typer av saker.

I de nordiske land nyter den lovgivende makt - med de folkevalgte parlamentene i forsetet tradisjonelt et særlig krav på respekt. Virksomheten i den utøvende makt - grovt sagt: den offentlige forvaltningen - er ofte avledet av beslutninger som treffes i parlamentet, eller de er i det minste avhengig av parlamentets langsiktige aksept. Derfor kommer spørsmålet om det forsvarlige i domstolskontroll med lovgivning i et demokratisk samfunn (den normative legitimiteten), på spissen mer i relasjon til den lovgivende enn den utøvende makt. De følgende bemerkninger avgrenses i samsvar med dette.

\footnotetext{
${ }^{2}$ Grunnlovens status som positiv rett (se nedenfor) tilsier at også de facto-forvaltningsdomstoler har slik kompetanse. At den faktisk har vært i bruk, ser vi for eksempel i de sakene for Trygderetten som i siste instans ble avgjort av Høyesterett i Rt. 1996 s. 1415 (Borthen) og Rt. 1996 s. 1440 (Thunheim).
} 


\section{Domstolskontrollen med lover mv.}

Domstolenes kompetanse til å prøve om ordinære lover holder seg innenfor grunnlovens grenser kan også uttrykkes ved å si at de nasjonale grunnlovene teller som positiv rett. ${ }^{3}$ Dette kan riktignok gjelde i ulik grad for ulike deler av konstitusjonen. Her hjemme får rettighetsspørsmål størst oppmerksomhet. Men eksempler fra både Norden og andre land illustrerer at også spørsmål av institusjonell karakter vil kunne bli avgjort av domstoler - til dels med viktige praktiske konsekvenser. Dette kan for eksempel gjelde myndighetsfordelingen mellom føderasjon og delstat (i for eksempel Tyskland og USA) eller mellom stat og kommuner (i flere land). Det kan gjelde retten til å oppløse parlamentet selv om regjeringens flertall ikke er truet. ${ }^{4}$ Og kravet om hjemmel i lov for visse disposisjoner («legalitetsprinsippet») handler ikke primært om rettigheter, men om kompetansefordelingen mellom den lovgivende makt og (særlig) forvaltningen; her har vi mye rettspraksis i Norge.

Samtidig er det i praksis store ulikheter mellom domstolskontrollen med lover fra våre syv høyeste rettsinstanser. I Finland og Sverige er både kontrollens formelle eksistens og dens betydning i praksis av relativt ny dato (og betydningen er fortsatt svært begrenset, $\mathrm{i}$ alle fall målt etter antall saker der lovbestemmelser blir underkjent av hensyn til grunnloven). I Danmark peker kontrollens uttrykkelige anerkjennelse (gjennom høyesterettspraksis) omtrent 100 år tilbake i tid; men hittil har bare én lovbestemmelse blitt sagt eksplisitt til side. $^{5}$

I Island har kontrollens praktiske rolle vært større. Men Norge er likevel eneste land i Norden der domstolene - med Høyesterett i spissen - gjennom snart to hundre år har spilt en tidvis både markant og synlig rolle i saker av konstitusjonell karakter. De videre bemerkningene vil stort sett bli konsentrert om Norges høyesterett.

\footnotetext{
${ }^{3}$ Se for eksempel Eivind Smith, Konstitusjonelt demokrati, 3. utgave, Bergen 2015 kap. II.6 og andre steder.

${ }^{4}$ Dette har skjedd i Tyskland, der grunnloven legger stor vekt på å sikre institusjonell stabilitet. For eksempler, se Smith, Konstitusjonelt demokrati (2015), kap. III.5.5.2.

${ }^{5}$ UfR $1999.841 \mathrm{H}$, Tvind (som også ble publisert på samme måte som lover).
} 
I rettspraksis kan den norske grunnlovens status som positiv rett spores tilbake til det første tiåret etter 1814, nærmere bestemt rundt $1820 .{ }^{6}$ Kort etter at Høyesteretts medlemmer gjennom lov (1863) ble påtvunget offentlig, individuell votering, trådte den første gang offentlig frem gjennom domspremisser i den kjente Wedel-Jarlsberg-saken i $1866 .{ }^{7}$ Senere er det særlig grunn til å trekke frem en periode der Høyesterett i årene etter 1909, i en rekke saker om økonomisk reguleringslovgivning opptrådte på en måte som i ettertid gjerne betraktes som «aktivistisk». Dette utløste politisk strid og gradvis tilbaketrekning fra Høyesteretts side; kanskje kan vi altså tale om Norges «New Deal»-kamp 20 år før den langt bedre kjente feiden mellom president Roosevelt og høyesterett fant sted i USA.

På denne bakgrunn fremtrer gjenreisningsperioden etter 1945 som en lang stillstand; i noen saker kunne vi tale om «aktivisme» i revers, i den forstand at $\mathrm{H} \varnothing$ yesterett gjorde sitt beste for å tolke grunnloven slik at den ikke sto i veien for ordinær lov. Fra 1970-årene ble denne perioden avløst av en viss renessanse. ${ }^{8}$ Og fra ca. år 2000 har utviklingen skutt fart; de tre plenumsdommene om grunnlovsrelaterte spørsmål i 2010 står som ubestridt høydepunkt (eller lavmål, for de mest skeptiske). ${ }^{9}$

Utviklingen har skjedd parallelt med at høyesterettspraksis avspeiler $\varnothing$ kende vekt på Den europeiske menneskerettskonvensjon (EMK) og andre internasjonale regelverk som stort sett har vært inkorporert i norsk rett gjennom ordinær lovgivning. Tallmessig har det vært langt flere slike saker enn saker om forholdet mellom grunnlov og lov. Den tenkningen som ligger bak denne delen av rettspraksis har sikkert påvirket Høyesteretts selvforståelse også på det konstitusjonelle området. Grunnlovfestingen (2014) av hovedbestemmelsene i EMK (og enkelte andre konvensjonsbestemmelser) har ikke lagt noen demper på utviklingen.

\section{Grunnlovfesting: § 89}

På samme måte som i Danmark vokste norske domstolers kontroll med at grunnloven har vært respektert i konkrete saker, frem uten eksplisitt st $\varnothing$ tte i grunnlovens tekst. I anledning

\footnotetext{
${ }^{6}$ Se nærmere Eivind Smith, Høyesterett og folkestyret, Oslo 1993, s. 119 f.

7 UfL 1866 s. 165.

${ }^{8}$ Smith, Høyesterett og folkestyret (1993), del VII.

${ }^{9}$ Rt. 2010 s. 143 (rederiskatt), Rt. 2010 s. 535 (Opplysningsvesenets fond - OVF) og Rt. 2010 s. 1445 (krigsforbrytelse).
} 
Høyesteretts 200 års jubileum i 2015 ble dette endret hos oss: Ifølge grunnloven § 89 har domstolene «rett og plikt til å prøve om lover og andre beslutninger truffet av statens myndigheter strider mot Grunnloven» (bokmålsversjonen).

At denne oppgaven bare tilkommer domstolene «i saker som reises for» dem, er i og for seg en selvfølge; utgangspunktet er jo at domstolene ikke initierer sine egne saker. Men vi vet også at dette ikke uten videre står i veien for at dommerne vektlegger bestemte sider av de sakene de får inn. Og hvis utgangspunktet om grunnloven som positiv rett tas på alvor (se ovenfor), må domstolene reise og ta standpunkt til konstitusjonelle sider av en sak selv om partene ikke selv har utformet argumentasjonen på denne måten; i grunnlovsbestemmelsen kan vi legge dette inn i passusen om «plikt».

Det er flere grunner til at $\S 89$ er uheldig formet. ${ }^{10}$ Dette skyldes allerede at kontrollen med om forvaltningen har respektert loven (legaliteten) ikke har kommet med. Dermed går vi glipp av den viktigste delen av rettspraksis om kontroll med de andre statsmaktene: Den har

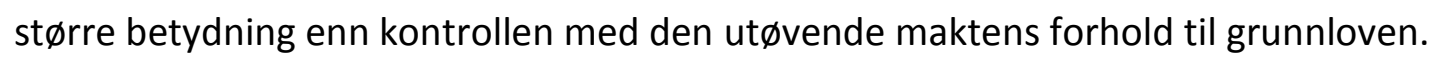

I denne artikkelen er det likevel særlig grunn til å nevne den formuleringen som er valgt for å få domstolskontrollen med lover inn i grunnlovens tekst: Det domstolene skal kunne prøve, er om «lover ... strider mot Grunnloven». Om vi tar formuleringen på ordet, innebærer den at vi nå har fått en ordning for det som i komparativrettslig lys kan betegnes som abstrakt kontroll, det vil si kontroll med om lovbestemmelsen $i$ seg selv strider mot konstitusjonen. Dette ville imidlertid utgjøre et markant brudd med tradisjonen i både Norge (gjennom snart 200 år) og Norden for $\varnothing$ vrig: Kontrollens gjenstand hos oss er lovens anvendelse i den enkelte sak, med de muligheter for fleksibilitet og nyansering som dette gir (konkret kontroll).

Abstrakt kontroll gjelder altså rettsregelens som sådan. Også kontroll av konkret karakter kan få betydning for lovbestemmelsens videre skjebne. Men i vårt system er rettsavgjørelser bindende for partene, ikke for andre. Selv om anvendelsen av den var grunnlovsstridig i den saken som er endelig avgjort av domstolene, faller ikke loven bort. Dermed er det opp til den lovgivende makt å oppheve eller endre bestemmelsen hvis det er nødvendig for å unngå flere rettssaker om samme konstitusjonelle spørsmål, eller å endre loven på en slik måte at

\footnotetext{
${ }^{10}$ Se nærmere Eivind Smith, «Flere menneskerettigheter i grunnloven?», Lov og rett, 2012 s. 323-338 på s. 328 flg. Ordlyden er foreslått endret, se Dok. 12:19 (2015-2016) Grunnlovsforslag.
} 
omtrent samme politiske mål kan nås med andre midler. Etter at grunnloven $§ 100$ fjerde ledd om absolutt forbud mot forhåndssensur var vedtatt, tok det for eksempel flere år før lovbestemmelsene om filmsensur mv. selv om filmen bare skulle vises for voksne, ble fjernet. Situasjonen ble imidlertid løst ved at Medietilsynet innrettet seg på det som fulgte av den nye grunnlovsbestemmelsen.

Systemet for konkret kontroll kan blant annet forsvares ved å vise til at det materialet som nordiske domstoler typisk råder over, egner seg bedre til å vurdere argumenter og konsekvenser i den enkelte sak enn for å avgjøre hvordan lovgivningen i og for seg bør se ut. Under ellers like forhold er abstrakt kontroll av langt tydeligere «politisk» karakter enn kontroll ut fra forholdene i den enkelte sak.

Vedtaket om grunnloven § 89 tok sikte på å synliggjøre det etablerte systemet for domstolskontroll, ikke å innføre eller åpne for noe nytt. Om videreføringen av systemet for konkret kontroll uttaler flertallet i kontroll- og konstitusjonskomiteen blant annet:

«Ordlyden indikerer også at domstolskontrollen i Norge er en konkret kontroll, som gjelder anvendelsen av loven i konkrete saker som er reist, og der rettsvirkningen formelt er begrenset til sakens parter (inter partes). Virkningen av at norske domstoler finner en lov grunnlovsstridig er altså at den grunnlovsstridige lovbestemmelsen ikke får anvendelse i den konkrete saken. Deretter er det formelt opp til Stortinget å vurdere om og hvordan loven skal endres i samsvar med Grunnloven. ${ }^{11}$

Under debatten var det likevel delte meninger om det sannsynlige - og eventuelt ønskelige i at grunnlovfesting ville forsterke domstolenes posisjon overfor den lovgivende makt. Denne debatten kan også spores i komitéinnstillingen; Senterpartiets medlem av komiteen mente for eksempel at grunnlovfestingen «kan komme til å gi Høyesterett et frasparkspunkt for ytterligere å kunne øke sin kompetanse og makt». ${ }^{12}$

Noen utviklingstrekk som vi skal se nærmere på, kan nettopp gi grunn til å spørre om det vil kunne gå troll i grunnlovsparagrafens ord om abstrakt grunnlovskontroll.

\footnotetext{
11 Jf. Innst. 263 S (2014-2015) på s. 11.

12 Jf. Innst. 263 S (2014-2015) på s. 13.
} 


\section{Nærmere om Høyesteretts konstitusjonelle rolle}

Som allerede nevnt, er rettspraksis om konstitusjonelle spørsmål fra Norges høyesterett den mest langvarige og omfattende i Norden. Det meste tilsier at Høyesteretts aktivitet på dette området har tiltatt de siste tiårene. Utviklingen skyldes neppe at staten har blitt så mye slemmere enn før. I stedet har det nok sammenheng med at dommerne har blitt mindre bekymret for det legitime i å kontrollere politiske flertallsvedtak i den nest høyeste form konstitusjonen kjenner, nemlig lover vedtatt av vårt høyeste folkevalgte organ og stadfestet av den ut $\varnothing$ vende makt (jf. grunnloven $\S \S 76-78),{ }^{13}$ enn i flertallsstyreideologiens glanstid etter $1945 .^{14}$

Inntrykket fra internasjonale domstoler som Den europeiske menneskerettsdomstol har nok bidratt vesentlig til å svekke Høyesteretts frykt for å opptre som en «kjepp i demokratiets hjul». ${ }^{15}$ Dette avspeiles i praksis der den selv anvender traktatfestede normer som er gjort til nasjonal rett. Hvorfor skulle det være mer betenkelig å anvende vår egen grunnlov?

Den økende selvtilliten på det konstitusjonelle området har gitt en rekke praktiske utslag. De mest synlige er nok de tre plenumsdommene der Høyesterett i 2010 gir uttrykkelig beskjed om at grunnloven sto i veien for å anvende de omstridte lovbestemmelsene. Sakene handlet om at bestemmelser om rederiskatt var i strid med forbudet mot retroaktiv lov (grunnloven $\S 97),{ }^{16}$ om at den bruk av midler fra Opplysningsvesenets fond som det var åpnet for gjennom lovendring, ${ }^{17}$ var i strid med grunnloven $\S 116,{ }^{18}$ og om at anvendelsen av nye straffebestemmelser om krigsforbrytelser på begivenheter under krigen i Jugoslavia tidlig på 1990-tallet ville stride mot grunnloven $\S 97 .{ }^{19}$

Både i norsk og nordisk sammenheng er dommene til dels spektakulære. Dette skyldes ikke bare de $\varnothing$ konomiske interessene som var involvert i to av sakene (i saken om rederiskatt rundt regnet NOK 15 milliarder). Det skyldes heller ikke at Høyesterett, med en sentral menneskerettsjurist (Erik Møse) som førstvoterende, tilsynelatende opptrådte til fordel for

\footnotetext{
13 Jf. særlig Eivind Smith, «Høyesterett - en trussel mot demokratiet?», Lov og rett, 1999 s. 451-486.

14 Jf. Smith, Konstitusjonelt demokrati (2015), kap. $1.4 \mathrm{flg}$.

${ }^{15}$ Om dette bildet, jf. Smith, Høyesterett og folkestyret (1993) kap. 1 med videre henvisninger.

${ }^{16}$ Rt. 2010 s. 143.

${ }^{17}$ Rt. 2010 s. 535.

${ }^{18} \mathrm{~F} \varnothing \mathrm{r}$ omnummereringen i mai 2014 var det tale om § 106, som dommen følgelig gjelder.

${ }^{19}$ Rt. 2010 s. 1445.
} 
en krigsforbryter. Men det skyldes at retten i de to første sakene grep inn mot bestemmelser som var blitt vedtatt etter skarp politisk strid og med tilsvarende knapt flertall i Stortinget, og dermed på sett og vis grep inn på opposisjonens side i saker med sterke politiske overtoner, og i den tredje saken mot lovendringer som - i det godes tjeneste - ble omfavnet fra alle politiske hold. Det skyldes også at Høyesterett, under dissens, ga omsvøpsløs beskjed om at de til dels uvanlig inngående vurderingene av de aktuelle bestemmelsenes forhold til grunnloven som hadde vært foretatt under lovforberedelsen i Stortinget, var uten betydning for resultatet. ${ }^{20}$ Dessuten skjer tilsidesettelsene i alle tre saker under uttrykkelig beskjed om at de er grunnlovsstridige.

Veien er altså langt fra den viktigste saken i domstolskontrollens «renessanse» (se ovenfor), nemlig Rt. 1976 s. 1 (Kløfta): Her tar premissene utgangspunkt i at Stortingets forståelse av lovens forhold til grunnlovsbestemmelser om økonomiske rettigheter «må spille en betydelig rolle når domstolene skal avgjøre grunnlovmessigheten, og domstolene må vise varsomhet med å sette sin vurdering over lovgiverens». Og i stedet for å erklære at den aktuelle lovbestemmelsen (om beregning av erstatning ved ekspropriasjon) stred mot kravet om «full erstatning» etter grunnloven $\S 105$, valgte Høyesterett en grunnlovskonform tolkning; lovbestemmelsen kunne altså anvendes uten å komme i strid med grunnloven.

Høyesteretts nye vilje til å tale klart er ikke på noen måte kritikkverdig. Sammenlignet med den mulighet til å rykke frem uten å lage for mye støy som ligger i bruk av grunnlovskonform tolkning, med sin glidende overgang mot «alminnelig» tolkning med eller uten grunnloven $\mathrm{i}$ bakgrunnen, er den tvert imot å foretrekke: En slik fremgangsmåte er langt bedre egnet til å skape debatt om både Høyesteretts standpunkt og de behov for å endre grunnlov eller lov som saken kan tenkes å avdekke.

Den klarhet om at loven faktisk blir satt til side som vi finner i flere nyere avgjørelser, passer godt inn i bildet av Høyesterett som en domstol med større selvtillit på det konstitusjonelle området enn for få tiår siden.

Tendensen til å utforme domspremissene med sikte på en abstrakt snarere enn en konkret kontroll med den aktuelle lovbestemmelsens forhold til grunnloven (se ovenfor om dette

\footnotetext{
${ }^{20}$ I de to førstnevnte sakene hadde vedkommende stortingskomité endog gjort noe så uvanlig som å holde åpen høring om grunnlovsspørsmålet.
} 
skillet) føyer et annet trekk til et slikt bilde. I et system der domstolskontrollen bare kan ta sikte på å avgjøre om overordnet rett er brutt overfor en eller flere parter i en bestemt sak, må domskonklusjonen formes konkret. Dermed må vi gå til domspremissene for å få beskjed om rettens grunnlag for konklusjonen - noe det ofte er bare (andre) jurister som gjør.

Noen ganger faller resultatet i den enkelte sak og når det gjelder lovens grunnlovmessighet i og for seg, praktisk sett omtrent sammen. Den ovennevnte dommen i Rt. 2010 s. 535 gir et klart eksempel: Saken gjaldt utelukkende den formuesmassen som ifølge grunnloven § 116 skal forvaltes etter bestemte regler og som gjerne omtales som «Opplysningsvesenets fond» (OVF). ${ }^{21}$ Men det finnes jo bare én slik formuesmasse. Dermed måtte Høyesteretts syn på om grunnloven § 116 var trådt for nær, nødvendigvis bli avgjørende ikke bare for OVF selv, men også for den omstridte lovbestemmelsen selv. ${ }^{22}$

Men også ellers er det mange eksempler på at Høyesterett gjerne uttrykker seg mer generelt - eller altså: abstrakt - enn den aktuelle saken i og for seg gjør nødvendig. Selv har jeg brukt dommen om barns rett til gratis fiske i ferskvann som eksempel. ${ }^{23}$ Her utbrer premissene seg om lovens forhold til kravet om full erstatning ved ekspropriasjon (§ 105). Grunneieren som hadde brukt tid og krefter på å få saken rettslig belyst - ble nærmest avspist med en beskjed om at han alltids kunne $s \varnothing k e$ fylkesmannen om dispensasjon. ${ }^{24}$ «Men rekninga måtte ... partane ta da kollokviet var over. $)^{25}$

Senere har denne tendensen særlig fått oppmerksomhet i kjølvannet av grunnlovsreformen i 2014. Her har blant annet Kinander påpekt en slående tendens til å argumentere med overordnede normer (nye grunnlovsbestemmelser - stort sett belyst gjennom parallelle traktatbestemmelser og -praksis) i saker som lett kunne ha vært løst ved anvendelse av de

\footnotetext{
${ }^{21}$ Betegnelsen følger nå av lov 7. juni 1996 nr. 33 om Opplysningsvesenets fond.

${ }^{22}$ Lovbestemmelsen falt likevel ikke bort som følge av Høyesteretts dom, men måtte på vanlig måte oppheves av domstolen selv (se lov 26. august $2011 \mathrm{nr}$. 40).

${ }^{23}$ Rt. 2004 s. 1985.

${ }^{24}$ Se for eksempel Smith, Konstitusjonelt demokrati (2015), s. 312.

${ }^{25}$ Kåre Lilleholt, «Argumentasjonsmønsteret i høgsterettspraksis frå dei seinare åra», Tidsskrift for Rettsvitenskap, 2002 s. 62-75 del 4 (om «regelorienterte og teoriprega premissar»).
} 
ordinære lovbestemmelsene på området. ${ }^{26}$ Det er god grunn til å anta at de aktuelle sakene tidligere ville ha vært løst på denne måten.

Når Høyesterett går veien om overordnede, og dermed gjerne mer generelt utformede, bestemmelser med et tilsvarende usikkert innhold, vil den kunne skaffe seg større frihet til å utforme norsk rett i samsvar med det innhold som retten selv tillegger de overordnede «prinsipper» enn hvis den går rett på den aktuelle lovbestemmelsen. Men dermed tar den nødvendigvis skritt i retning av en genuin lovgiverfunksjon. Dette skjer uten at den kan påberope seg den lovgivende maktens demokratiske legitimitet i våre samfunn og uten den mulighet for å gi politiske omvurderinger uttrykk gjennom flertallsvedtak som den ordinære lovgivningsprosessen gir: ${ }^{27}$ Det «riktige» svaret følger jo av (Høyesteretts tolkning av) grunnloven, må vite.

\section{6 «Rettsenhet, rettsavklaring og rettsutvikling»}

Tendensen til denne formen for abstrakt domstolskontroll har utvilsomt sammenheng med den vekt som nå blir lagt på Høyesteretts rolle som presedensdomstol og på dens «rettsutviklende» oppgave.

Vekten på presedensfunksjonen har solid støtte i lovgivningen: Tvisteloven (2005) § 30-4 bestemmer således at $\mathrm{H} \varnothing$ yesterett bare kan behandle anker over dommer i sivile saker «når anken gjelder spørsmål som har betydning utenfor den foreliggende sak, eller det av andre grunner er særlig viktig å få saken avgjort i Høyesterett».

Oppgaven med å «utvikle retten» er i langt større grad domstolens eget påfunn. ${ }^{28}$ Den inngår som en del av «Høyesteretts hovedoppgave» slik den nå fremheves på forsiden av rettens nettsider: Høyesterett skal «arbeide for rettsavklaring og rettsutvikling». ${ }^{29}$ Det er i

\footnotetext{
${ }^{26}$ Morten Kinander, «Fra tilbakeholdenhet til aktivisme - nyere utviklingslinjer i forholdet mellom rett og politikk i Høyesterett», Lov og rett, 2016 s. 141-164. DOI: http://dx.doi.org/10.18261/issn.1504-3061-2016-0303

${ }^{27}$ Om korreksjonsmuligheten, se blant annet Smith, Konstitusjonelt demokrati (2015), kap. 7.3.2 og Kinander, «Fra tilbakeholdenhet til aktivisme - nyere utviklingslinjer i forholdet mellom rett og politikk i Høyesterett» (2016), s. 159 og s. 163.

28 Jf. Anne Robberstad, «Høyesteretts mandat», Lov og Rett, 2016 s. 245-256. DOI:

http://dx.doi.org/10.18261/issn.1504-3061-2016-04-11

${ }^{29}$ http://www.domstol.no/hoyesterett
} 
seg selv interessant at målet om «rettsenhet» synes å ha blitt borte på veien. Alene tilbake står de langt mer dynamiske oppgavene «avklaring» og «utvikling».

Høyesteretts «formål» bygger ikke på bestemmelser i lov. Den har i stedet vokst frem under innflytelse fra daværende justitiarius Carsten Smith. ${ }^{30}$ Senere har den vært dyrket både av hans etterfølger (Tore Schei) og av institusjonen selv.

Det elementet som ikke lenger nevnes på nettsidene (rettsenhet), gir egentlig seg selv: Landets $\emptyset$ verste rettsinstans kan ikke først og fremst ha som mål å sørge for at alle enkeltavgjørelser av lavere instanser er «riktige», men å bidra til at retten blir mest mulig enhetlig overalt i landet. At dette arbeidet kan reise spørsmål som ikke har noe klart svar og derfor trenger «avklaring», overrasker ingen jurister.

Det er heller ikke overraskende at «rettsavklaring» både kan og - ikke sjelden - må medføre en viss «rettsutvikling». På den noe mer detaljerte nettsiden «Om Høyesterett» utdypes dette ved å si at retten «også» har «et ansvar for rettsutviklingen, innenfor lovgivningens rammer, der nye samfunnsproblemer krever det». Målet om rettsutvikling «innenfor lovgivningens rammer» stemmer godt med forarbeidene til tvisteloven § 30-4 (se ovenfor). ${ }^{31}$ Men forarbeidenes tillegg om at dette skal skje «i samspill med de lovgivende myndigheter», særlig der «Stortinget har overlatt den videre rettsutvikling til domstolene», finner vi ikke igjen i Høyesteretts versjon. Slik «delegert» rettsutvikling kan typisk gjelde lovbestemmelser av sterkt skjønnsmessig karakter, så som rettslige standarder av typen «urimelig» eller «uanstendig» (straffeloven § 298).

I stedet fremstilles denne oppgaven som årsak til - eller begrunnelse for - en sterk presedens-orientering: «Derfor» vil «saker som «reiser prinsipielle spørsmål ut over det konkrete saksforhold, ... ofte slippe inn til behandling». ${ }^{32}$

Dessuten kan jo djevelen også her vise seg å bo i detaljene: Det er sjelden opplagt hva nye samfunnsproblemer «krever». Uten hensyn til om svaret er gjenstand for politisk strid, er det jo i bunn og grunn tale om spørsmål av politisk karakter som da - i alle fall som hovedregel - bør løses av politisk ansvarlige organer. I motsetning til dette er domstolenes

\footnotetext{
${ }^{30}$ Ansatser finnes allerede i hans foredrag om «Domstolene og rettsutviklingen», Lov og Rett, 1975 s. 292-319.

${ }^{31}$ Ot.prp. nr. 51(2004-2005) på s. 302-303.

${ }^{32}$ http://www.domstol.no/no/Enkelt-domstol/-Norges-Hoyesterett/Om-Hoyesterett/
} 
hovedoppgave tradisjonelt å presisere og anvende de rettslige løsninger som antas å følge av de politiske vedtak i form av lov mv. som til enhver tid gjelder. Det kan meget vel hevdes at rettsutvikling ut over det som følger av behovet for «rettsavklaring», bør skje gjennom politiske vedtak (som Høyesterett selvsagt kan påpeke at det etter dens syn er behov for). Resultatet ville da bli at man dømte i samsvar med gjeldende lov inntil regelverket eventuelt er endret.

Også passusen om at «behovet» for rettsutvikling begrunner behandling av «saker som reiser prinsipielle spørsmål ut over det konkrete saksforhold», kan gi kreative dommere en åpning for å «utvikle retten». En mulighet er selvsagt at det kun er tale om utvikling i form av avgjørelser som avklarer retten på en slik måte at nye saker om tilsvarende saksforhold, som regel vil være overflødige. Men i så fall hadde adjektivet «prinsipielle» vært overflødig.

Ordvalget kan med fordel sees i sammenheng med at ordet prinsipp er svært åpent og rent faktisk brukes på svært ulike vis, og med at det i mange land er en økende tendens til å resonnere om juridiske spørsmål via «prinsipper». Den som går veien om «prinsipper» for å avgjøre den enkelte sak, kan skaffe seg betydelig frihet i arbeidet med å «dedusere» det «riktige» svaret. Det samme gjelder anvendelsen av svært generelt formulerte rettsregler i den enkelte sak.

Endelig er det grunn til å minne om at ambisjonene om «rettsavklaring» og «-utvikling», etter omstendighetene kan komme i strid med hverandre. Muligheten for at Høyesterett vil kunne «utvikle» retten ut over hva det ellers kunne være grunn til å vente ut fra det aktuelle rettskildematerialet, skaper usikkerhet både for partene og for rettslivet mer allment. Men dermed ender vi lett opp med det motsatte av den «avklaringen» som rettslivet - og samfunnet - har bruk for; innimellom kan spenstig «rettsutvikling» fra dommersetet til og med skape slike problemer i relasjon til idealet om forutberegnelighet at det kan være på sin plass å trekke forbudet mot retroaktiv normgivning etter $\S 97$ inn i diskusjonen.

Dermed er vi tilbake til de siste årenes tendens til at Høyesterett «hopper over» direkte anvendelige lovbestemmelser og heller begrunner sine avgjørelser ut fra grunnloven eller (for eksempel) EMK. I så fall har retten snudd fra å løse den konkrete saken til å gi uttalelser om grunnloven - med Iøsningen av det konkrete spørsmålet som konsekvens: Under ellers 
like forhold er det ikke tvil om at en slik fremgangsmåte øker domstolenes mulighet til selv å forme resultatet og/eller å identifisere «prinsipielle» løsninger av mer generell karakter.

Ordlyden i § 89, som angir at det ikke er lovens anvendelse i den enkelte sak, men dens eget forhold til grunnloven, som skal prøves, melder seg ubedt for tanken.

\section{Rettsutvikling og holdningen til Høyesteretts virksomhet}

Det er slett ikke gitt at entusiasmen for en utvikling som her er skissert, er likelig fordelt blant alle Høyesteretts dommere. Både praksis ${ }^{33}$ og litteratur ${ }^{34}$ indikerer tvert imot til dels betydelig ulikhet i synet på hvordan retten bør håndtere forholdet mellom dømmende virksomhet i tråd med et mer tradisjonelt syn i Norden, og rettsutvikling fra dommersetet. Offentlig fremførte uttrykk for enkeltdommeres syn kan altså ikke uten videre tillegges samme vekt som flertallsuttalelser fra dommersetet.

Samtidig har vi de siste årene stått overfor eksplisitte uttrykk for rettspolitiske programmer hos enkeltdommere i større grad enn det som har vært vanlig. Når slike programmer fremføres konsekvent over tid og synes å gi seg utslag i voteringene i en domstol der sammensetningen ( $\mathrm{i}$ avdelingene) stadig skifter, slik at meningsfeller lett kan komme i flertall i den dømmende formasjonen, er det ingen grunn til å overse slike uttrykk for et rettspolitisk program.

Arnfinn Bårdsen er nå den som viser størst aktivitet på dette området. Han har sittet $\mathrm{i}$ Høyesterett siden 2008. Både som forfatter og dommer har han satt spor etter seg som tilhenger av en aktiv, prinsipporientert domstol. Dette stemmer godt med hans faglige bakgrunn fra EMK-jusen.

\footnotetext{
${ }^{33}$ Dissensen i Rt. 2015 s. 1105 (Acta) gir et eksempel.

${ }^{34}$ Se for eksempel dommer Skoghøys implisitte, men kontante avvisning («Menneskerettighetenes stilling etter Grunnloven", Lov og Rett, 2015 s. 195-196) av dommer Bårdsens offentlig fremførte syn om at grunnloven $\S$ 92 innebærer inkorporering av en lang rekke menneskerettskonvensjoner på grunnlovs nivå. - I desember 2016 avviste både flertall (inkludert Bårdsen) og mindretall, uttrykkelig en slik argumentasjon (HR-2016-2554-P (Holship) avsnitt 70 og 140).
} 
Hans doktoravhandling handler om betingelsene for å realitetsbehandle private klager ved Den europeiske menneskerettsdomstolen; ${ }^{35}$ også resten av hans vitenskapelige produksjon handler stort sett om EMK-rettslige spørsmål. Det er neppe tilfeldig at denne formative fasen har satt spor i et rettspolitisk syn som han i de senere år har gitt uttrykk for i mange artikler og foredrag. Det er nok heller ikke tilfeldig at det er i saker med menneskerettslige aspekter at Bårdsen - i det perspektiv jeg her anlegger - har markert seg sterkest. Muligheten for slik fremtreden har $\varnothing$ kt etter at grunnloven i 2014 fikk en rettighetskatalog der de fleste nye bestemmelsene først og fremst tar sikte på å «ta EMK-rettighetene hjem». ${ }^{36}$

Orienteringen mot EMK og andre internasjonale menneskerettighetsinstrumenter er han selvsagt ikke alene om, verken blant dommere eller advokater. Men de færreste av dem har offentlig fremført et så tydelig program i denne retning som dommer Bårdsen. I et foredrag ville han således «belyse $\mathrm{H} \varnothing$ yesteretts virksomhet og rolle i saker der det offentlige er part med utgangspunkt $\mathrm{i}$ at den moderne retten og samtidens rettstenking er rettighetsorientert, dynamisk og internasjonal». ${ }^{37}$

Utsagnet tar form av en påstand om hva «den moderne retten og samtidens rettstenking» faktisk «er». Men den deskriptive fasaden kan ikke skjule at det er tale om et vidtrekkende program med potensielt vidtrekkende implikasjoner: «Retten» er ikke (bare) noe som «er», men (også) noe som skapes. Bårdsen selv og hans kolleger innehar nøkkelposisjoner i denne kreative virksomheten hos oss.

Hvis det ikke bare skal si det selvsagte (at lovgivningen mv. stadig utvikler seg), må adjektivet «dynamisk» antas å innebære at dommeren selv bør eller må sørge for «rettsutvikling», om «nødvendig» endog vekk fra det som til enhver tid er politisk bestemt - altså uten å avvente ny lovgivning mv.

Også påstanden om at retten er «internasjonal», er nokså selvsagt hvis meningen bare er å påpeke at store deler av norsk rett i dag er påvirket av folkeretten (EMK, EØS osv.). Men ikke

\footnotetext{
${ }^{35}$ Arnfinn Bårdsen, Krenkelser og klager: vilkårene for realitetsbehandling av private klager ved Den europeiske menneskerettighetsdomstolen, Bergen 1999.

${ }^{36}$ Bårdsens nyeste artikkel i Jussens Venner («Grunnloven, straffeprosessen og strafferetten - noen linjer i høyesteretts praksis etter grunnlovsreformen 2014», Jussens venner, 2017 s. 1-44) passer godt inn i et slikt mønster. DOI: http://dx.doi.org/10.18261/issn.1504-3126-2017-01-01.

${ }^{37}$ Arnfinn Bårdsen, «Private parters mulighet til å vinne frem i saker mot det offentlige» pkt. 12 https://www.domstol.no/globalassets/upload/hret/artikler-og-foredrag/seminar-tromsa-23-april-2015.pdf
} 
sjelden kan en nasjonal dommer selv velge å gjøre mer eller mindre ut av denne situasjonen. Anvendt på saker om nye grunnlovsbestemmelser som er sterkt påvirket av nettopp EMK, inkludert poenget om EMK som et «living instrument», er full utnyttelse av dette synspunktet egnet til å øke dommerens handlefrihet i den nye, «dynamiske» rettsorden som Bårdsen ser for seg. ${ }^{38}$

Det samme gjelder den åpent ideologiske «konstateringen» om rettighetsorientering: Tar det sikte på å få oss til å glemme at det finnes spenninger mellom målet om rettighetsvern og andre grunnleggende verdier i det politiske styringssystemet?

På denne bakgrunn skal jeg i det følgende nøye meg med å trekke frem noen uttalelser av Bårdsen i offentlig tilgjengelige artikler (som gjerne bygger på foredrag - eller omvendt). ${ }^{39}$ Som alle andre nevner han at $\mathrm{H} \varnothing$ yesteretts oppgaver som utgangspunkt er «begrenset til den konkrete sak». ${ }^{40}$ Men han fremhever samtidig at «virkningen praktisk sett [er] omtrent den samme» som ved abstrakt normkontroll: «Dersom konklusjonen er at loven strider mot grunnloven, medfører det at Høyesterett ikke gir loven den tilsiktede normative kraft». Selv om det, «som et utgangspunkt, ikke [er] spørsmål om loven som sådan er i strid med grunnloven», må det «likevel tas hensyn til helheten». ${ }^{41}$

Videre fremhever han at det «i slike saker» lett vil «oppstå behov for at Høyesterett foretar egne utredninger, før under og etter ankebehandlingen». Dette må leses på bakgrunn av at Høyesterett arbeider med sikte på en vesentlig utvidelse av utrederenheten. ${ }^{42}$ Slik Bårdsen ser det, har behovet for slik styrking sammenheng nettopp med ønsket om å uttrykke seg

\footnotetext{
${ }^{38}$ Kinander, «Fra tilbakeholdenhet til aktivisme - nyere utviklingslinjer i forholdet mellom rett og politikk i Høyesterett» (2016), på s. 163 mener å kunne skimte «et rettspolitisk prosjekt om å strukturere norsk rett i tråd med den internasjonale retten, og med det å øke domstolenes makt på bekostning av den politiske makten».

${ }^{39}$ Bidragene er gjerne tilgjengelige på Høyesteretts nettsider http://www.domstol.no/no/Enkelt-domstol/Norges-Hoyesterett/Artikler-med-mer/. Men deler av de mer generelle betraktningene fra Bårdsen mfl. som finnes der, kunne med fordel ha vært fremlagt i fora med betydelig større spredning, slik at de lettere kunne gjøres til gjenstand for offentlig debatt.

${ }^{40}$ Arnfinn Bårdsen, «Norges Høyesterett som konstitusjonsdomstol», Lov, sannhet, rett, Oslo 2015, på s. 301.

${ }^{41}$ Bårdsen, «Norges Høyesterett som konstitusjonsdomstol» (2015), s. 315.

${ }^{42}$ Saksforberedelsen til plenumsdommen i Rt. 2015 s. 1388 (i en utlendingssak) gir et interessant eksempel, se nærmere Marius Stub, «Noen kommentarer til Rt. 2015 s. 1388», Jussens Venner, 2016 s.92-118, på s. 109, som bl.a. opplyser at Høyesterett på egen hånd hadde innhentet materiale fra konstitusjonsdomstolen i 17 land. DOI: http://dx.doi.org/10.18261/issn.1504-3126-2016-02-02.
} 
mer generelt - eller altså: prinsipielt. Tanken går lett til slike fagsekretariater som vi finner ved de spesialiserte konstitusjonsdomstolene i praktisk talt hele Europa utenfor Norden.

Med særlig sikte på domstolskontroll med lover fremhever Bårdsen at grunnloven må tolkes selvstendig, det vil - i norsk sammenheng - si uten at det syn på grunnlovens innhold som kommer til uttrykk i Stortinget under forberedelsen av omstridte lovbestemmelser, skal tillegges slik vekt som Høyesterett selv anviste i Rt. 1976 s. 1 (Kløfta). ${ }^{43}$ Men han går lenger og hevder at det «naturligvis ikke gjelder noen alminnelig rettslig presumsjon for at loven er grunnlovsmessig»; 44 i praksis har det "gjennomgående vist seg at Stortingets egen avveining ikke i seg selv har fått avgjørende betydning». ${ }^{45}$ I stedet skal domstolene tolke grunnloven «ut fra bredere avveininger av motstridende hensyn og interesser som har grenseflater mot de politiske overveielser som ligger til grunn for Stortingets beslutning om å vedta loven. Til dette kommer rettens dynamiske side ... grunnlovstolkning er krevende, og en så kompleks juridisk operasjon»

at det lett oppstår uenighet. Blant annet i grunnlovssaker vil dommerens standpunkt derfor «kunne preges av ideologiske, sosiale og personlige forhold, og av det tankesettet vedkommende har med seg fra sitt virke før utnevnelsen som dommer i Høyesterett».

Dette er ikke originalt, og neppe heller kontroversielt. Mer uvanlig er det nok at påpekningen kombineres med det syn at «grunnlovstolkningen må utvikles og ... grunnlovsnormene ... anvendes med sikte på dagens - ikke fortidens - samfunnsforhold, verdisyn, rettsoppfatninger og behov». Dette handler altså om «synet på grunnloven som et levende instrument». ${ }^{46}$ Det er ikke vanskelig å få øye på sammenfallet med den nøkkelformuleringen vedrørende tolkning av EMK som Den europeiske menneskerettsdomstolen (EMD) lenge har dyrket.

Tolkningen kan gjøre det «nødvendig å begrense eller myke opp», eller den kan vise at det er «påkrevet med utvidelse eller avstivning». ${ }^{47}$ Det inntrykk fester seg at Høyesteretts egnethet

\footnotetext{
${ }^{43}$ På dette punkt er jeg enig, se for eksempel Smith, Konstitusjonelt demokrati (2015), kap. VII.6.2.

${ }^{44}$ Bårdsen, «Norges Høyesterett som konstitusjonsdomstol» (2015), s. 306.

${ }^{45}$ Bårdsen, «Norges Høyesterett som konstitusjonsdomstol» (2015), s. 314 (også dette stemmer nok med mitt eget syn, se for eksempel Smith, Konstitusjonelt demokrati (2015), kap. VIII.6.3).

${ }^{46}$ Bårdsen, «Norges Høyesterett som konstitusjonsdomstol» (2015), s. 307.

${ }^{47}$ Bårdsen, «Norges Høyesterett som konstitusjonsdomstol» (2015), s. 308.
} 
til å avgjøre hva som i denne sammenheng er «nødvendig» eller «påkrevet», tas som gitt. I alle fall er det ikke lett å få øye på nærmere diskusjon av dette mildt sagt kilne temaet, sett i lys av for eksempel antagelsen om at dommerens standpunkt «i grunnlovssaker kan være preget av ideologiske, sosiale og personlige forhold» (se ovenfor).

Bårdsens fremfører også - uten nærmere kommentarer - en kontroversiell påstand om at «innflytelsen fra US Supreme Court [har] vært betydelig». Dette blir enda mer påfallende når påstanden står som premiss for det «naturlige» i «at Høyesterett også i dag følger med på praksis fra toneangivende nasjonale domstoler [i andre land] som avgjør konstitusjonelle spørsmål». ${ }^{48}$ Men utbyggingen av utredningsapparatet i Høyesterett (se ovenfor) kan sikkert bidra til en slik utvikling. Det samme gjelder de mange bes $\varnothing \mathrm{k}$ og andre kontakter mellom Høyesterett og flere særskilte konstitusjonsdomstoler i Europa som har funnet sted særlig under ledelse av Carsten Smith og Tore Schei.

\section{Høyesterett - en «konstitusjonsdomstol»?}

Det er nok slike holdninger til dommerrollen som er skissert ovenfor, som ligger bak når Bårdsen har begynt å snakke om Høyesterett som «konstitusjonsdomstol». Første gang det skjedde offentlig var antagelig i et foredrag på et nordisk seminar for høyesterettsdommere i Stockholm i mars 2015; tittelen kunne endog tyde på at alle høyesteretter i Norden fortjener en slik karakteristikk. ${ }^{49}$

Senere er betegnelsen benyttet blant annet i et parallellforedrag (på engelsk) i Wien, ${ }^{50}$ antagelig fremført under $\mathrm{H} \varnothing$ yesteretts bes $\varnothing \mathrm{k}$ til $\emptyset$ sterrikes konstitusjonsdomstol og dermed med godkjenning av Høyesteretts ledelse, og i en artikkel til Høyesteretts 200 års jubileum, ${ }^{51}$ der domstolen endog karakteriseres som «Europas første konstitusjonsdomstol».

\footnotetext{
${ }^{48}$ Bårdsen, «Norges Høyesterett som konstitusjonsdomstol» (2015), s. 309.

${ }^{49}$ Arnfinn Bårdsen, «De nordiske høyesterettene som konstitusjonsdomstoler: Noen nyere utviklingslinjer $\mathrm{i}$ Norges Høyesterett» http://www.domstol.no/no/Enkelt-domstol/-Norges-Hoyesterett/Artikler-medmer/Nordisk-hoyesterettsdommerseminar/

${ }^{50}$ Dagfinn Bårdsen, «The Nordic Supreme Courts as Constitutional Courts» http://www.domstol.no/globalassets/upload/hret/artikler-og-foredrag/nordic-constitutional-courts---vienna29102015.pdf

${ }^{51}$ Bårdsen, «Norges Høyesterett som konstitusjonsdomstol» (2015), s. 291-316.
} 
Jeg har ikke inntrykk av at betegnelsen har slått rot i Norden utenfor Norge. I Norge later den derimot til å ha slått an, og da med særlig sikte på debatten om Bårdsens egen domstol. I forbindelse med Tore Scheis fratreden som justitiarius i februar 2016 publiserte ekteparet Anine Kierulf og Rune Slagstad for eksempel en artikkel der vi bl.a. kan lese at «Høyesteretts posisjon som konstitusjonsdomstol er i dag vel etablert og ble befestet ved grunnlovsreformen i 2014».52 - Om forholdet mellom ord og realitet i § 89 viser jeg til det som er sagt ovenfor.

Bårdsens ordvalg stemmer neppe så dårlig med Høyesteretts selvoppfatning slik den trer frem ikke bare gjennom hjemmesidenes understrekning av sin «rettsutviklende» rolle, men også med oversikten over dens internasjonale virksomhet. ${ }^{53}$ Ifølge årsmeldingen for 2014 deltok retten ikke bare i internasjonale nettverk eller foreninger for «Supreme Judicial Courts», men også for blant annet «European Constitutional Courts» og «Constitutional Justice». I 2015 var den representert på et møte for europeiske konstitusjonsdomstoler i Georgia og på bes $\varnothing \mathrm{k}$ hos $\varnothing$ sterrikes konstitusjonsdomstol. ${ }^{54}$

Deltagelse i nettverk av denne typen kan godt la seg forsvare ut fra funksjonelle forhold. At Høyesterett (som sisteinstans) har kompetanse også i saker om forholdet mellom lov og grunnlov, er på det rene. I Norge har slik virksomhet periodevis også spilt en ikke helt uvesentlig praktisk rolle.

Men derfra til å betegne Høyesterett som «konstitusjonsdomstol» er det et betydelig skritt. Enhver med kjennskap til komparativ rett om disse spørsmål vil se at en slik terminologi er påfallende. Den som tar seg bryet med å sette seg inn i litteraturen mv. om disse forhold, vil også se at det både funksjonelt og på andre måter er god grunn til å skille mellom egentlige konstitusjonsdomstoler og domstoler som har kontroll med lover som én del av sine oppgaver, oppgaver som for $\varnothing$ vrig omfatter mange rettsområder. De spesialiserte konstitusjonsdomstolene i Europa har røtter tilbake til tiden etter første verdenskrig og har deretter - etter 1945 - spredt seg til mange deler av verden. I motsetning til dette hører vår

\footnotetext{
${ }^{52}$ Morgenbladet 26. februar-3. mars 2016 s. 22 flg. på s. 23.

${ }^{53} \mathrm{http} / / / \mathrm{www}$. domstol.no/globalassets/upload/hret/arsmelding/arsmelding-2014.pdf

${ }^{54} \underline{\text { http://www.domstol.no/globalassets/upload/hret/arsmelding/arsmelding---2015.pdf }}$
} 
egen høyesterett hjemme i den hovedgruppen av domstoler som - blant andre oppgaver har visse konstitusjonelle beføyelser..$^{55}$

I Bårdsens første innlegg om saken (fra dommermøtet i Stockholm) står det lite om hva han selv forstår med konstitusjonsdomstoler. Men han konstaterer likevel at vi i Norden ikke har

«særskilte forfatningsdomstoler som utfører forhåndskontroll med lovgivningen, løser kompetansekonflikter mellom ulike forvaltningsnivåer, avgjør valgtvister eller mer generelt avgir responsa i grunnlovsspørsmål til regjering eller parlament. Men våre høyeste domstoler har alle sammen funksjoner som innebærer at vi i en viss forstand likevel er konstitusjonsdomstoler. Kjernen her er plikten til å sette til side en lov som viser seg å være i strid med våre respektive grunnlovers menneskerettsbestemmelser. Vi snakker ikke om å oppheve loven, og langt mindre om å treffe noe nytt lovvedtak. I sin enkleste form munner grunnlovskontrollen ut i at loven - så langt den er uforenlig med Grunnloven - blir stående uten normativ kraft i den aktuelle saken. På grunn av høyesterettsdommens prejudikatsvirkning vil loven dessuten mer generelt miste sin virkning, så langt det i dommen er slått fast at loven er grunnlovsstridig. Høyesterettenes stilling som statsmakter og som prejudikatsdomstoler er her altså to sider av den samme saken. $»^{56}$

Betegnelsen «konstitusjonsdomstol» er altså dekkende bare «i en viss forstand»; dette er et betimelig forbehold som kanskje ikke alle har fått med seg. Redusert til sin grunnform synes karakteristikken ellers å bygge på de nordiske høyesterettenes plikt «til å sette til side en lov som viser seg å være i strid med våre respektive grunnlovers menneskerettsbestemmelser»; saker om forholdet mellom de andre statsmaktene er visst tapt av syne, selv om de i alle fall i Norge har spilt en rolle gjennom mange år og fortsatt vil kunne gjøre det. ${ }^{57}$ Dette er klar tale; men karakteristikkens grunnlag blir tilsvarende magert.

I en senere artikkel $^{58}$ gir Bårdsen uttrykk for at han er klar over at ulikhetene mellom $\mathrm{H} \varnothing$ yesterett og «de rendyrkede konstitusjonsdomstoler ... mange steder i Europa ... er mange og store». I tillegg til de særtrekk som nevnes i Stockholms-foredraget, fremhever han nå at ulikhetene også knytter seg til «utnevnelsesprosedyre og funksjonsperiode for dommere». Han finner likevel ikke grunn til å kommentere disse viktige elementene

\footnotetext{
${ }^{55}$ Litteraturen om disse spørsmålene er omfattende. På norsk, se særlig Eivind Smith, «Rettslig håndheving av konstitusjonelle normer - i Europa og i Norge», Tidsskrift for Rettsvitenskap, 1983 s. 77-131 og Smith, Konstitusjonelt demokrati (2015), kap. VII.6.4.

${ }^{56}$ Bårdsen, «De nordiske høyesterettene som konstitusjonsdomstoler: Noen nyere utviklingslinjer i Norges Høyesterett», punkt 1.

57 På dette punkt er det verdt å nevne at den nye grunnlovsbestemmelsen om domstolskontroll (§ 89) ble tatt inn i del D om den dømmende makt, ikke i det nye menneskerettskapitlet, slik som opprinnelig foreslått.

${ }^{58}$ Bårdsen, «Norges Høyesterett som konstitusjonsdomstol» (2015), (de følgende sitater er fra s. 296 flg.).
} 
nærmere. Dette gjelder selv om han - som nevnt - trekker frem USAs høyesterett til sammenligning: Heller ikke dette er jo en konstitusjonsdomstol, men avviker unektelig fra vår høyesterett egen på mange punkter, ikke minst hva gjelder «utnevnelsesprosedyre og funksjonsperiode for dommere».

\section{Noen komparative elementer}

For tiden avsier Høyesterett rundt 100 dommer i året, omtrent halvparten i strafferett; dertil kommer et stort antall saker avgjort i ankeutvalget. Selv om store rettsområder sjelden eller aldri kommer opp for de ordinære domstolene, innebærer dette at den saklige spredningen er stor, særlig utenfor strafferettens område.

Dommernes mulighet for å spesialisere seg i konstitusjonelle spørsmål gjennom praksis blir tilsvarende liten. En utvidet utredningsenhet «for å møte den $\varnothing$ kte rettslige spesialiseringen, slik at dommerne fortsatt kan være generalister», slik Bårdsen nevner, ${ }^{59}$ kan sikkert være nyttig innenfor en del av de områdene som jurister typisk befatter seg med. Konstitusjonell rett er imidlertid av en annen karakter. Dette gjelder ikke minst fordi resultatene binder den lovgivende maktens handlefrihet for fremtiden på en helt annen måte enn dommer som beveger seg på lovgivningsplanet alene..$^{60}$

Behovet for innsikt i konstitusjonelt relevante spørsmål er en viktig del av bakgrunnen for at nesten alle land i Europa har valgt å etablere særskilte konstitusjonsdomstoler. Om dette behovet ikke ivaretas allerede ved oppnevningen, kan det skje gjennom den løpende virksomheten, der nettopp konstitusjonelle spørsmål dominerer arbeidsoppgavene (ikke bare etterhåndskontroll med lover, men ulike former for ex ante-kontroll, valgkontroll osv.). I vår tid blir Høyesteretts medlemmer utpekt gjennom en tilnærmet «politikkfri» prosedyre, der regjeringen i praksis alltid følger innstillingen fra et særskilt innstillingsråd for dommere, med påfølgende uttalelse direkte fra høyesterettsjustitiarius til justisministeren. Rådet har ni

\footnotetext{
${ }^{59}$ Arnfinn Bårdsen, «De nordiske høyesterettene som prejudikatdomstoler» http://www.domstol.no/globalassets/upload/hret/artikler-og-foredrag/nordiske-prejudikatsdomstoler-mars2016.pdf pkt. 25 .

${ }^{60}$ Jf. nærmere i Smith, Konstitusjonelt demokrati (2015), kap. II.4.
} 
medlemmer oppnevnt av Kongen. Fem representerer juristprofesjonene (tre dommere fra de alminnelige domstolene, en advokat og en offentlig ansatt jurist), to er ikke jurister.

På nettsidene opplyser rådet - korrekt nok - at formålet med ordningen verken var «et laugstyre hvor hele utnevnelsesprosessen ville skje innenfor domstolene» eller «en korporativ prosess med representanter fra arbeidsgiver og arbeidstakerne». ${ }^{61}$ Men det er ikke lett å komme unna at kollegiet er sterkt juristdominert. Muligheten for å balansere denne overvekten med flere «lege» medlemmer, kanskje endog oppnevnt av Stortinget, er ikke benyttet. En slik løsning ville vel st $\varnothing$ te an mot det utbredte idealet blant norske jurister om at kunnskap om dommerrekruttenes samfunnssyn eller - mer omsvøpsløst - deres politiske preferanser, nærmest er av det onde.

Dagens ordning ble innført omtrent samtidig som grunnloven $\S 62$ ble endret for å ta Høyesteretts medlemmer inn på listen over personkategorier som ikke kan velges til Stortinget. Denne endringen skjedde betegnende nok nokså ubemerket som ledd i en bredere valgreform. Kontrasten til 1800-tallet og første del av 1900-tallet er brutal: I den perioden da vårt system for domstolskontroll med lover vokste frem og ble befestet, spilte mange dommere en viktig rolle i politikk og samfunnsliv. Det er rimelig å tro at disse to forholdene henger sammen.

Embetet som justitiarius ble holdt utenfor da det nåværende systemet for «apolitisk» dommerrekruttering ble innført. Men regjeringens mulighet til å velge mellom aktuelle kandidater, slik det hadde vært gjennom det meste av grunnlovens eksistens, skapte debatt da Tore Scheis etterfølger skulle utnevnes vinteren 2015. Mange krevde faste regler også for denne utnevnelsen. Men det var nok en vel så viktig kilde til uro at justisministeren $\emptyset$ nsket å trekke Stortinget, nærmere bestemt presidentskapet, inn i prosessen.

Et annet særtrekk ved $\mathrm{H} \varnothing$ yesterett sammenlignet med typiske konstitusjonsdomstoler er fraværet av sentralisering av saker om konstitusjonelle spørsmål. Enhver dommer har plikt til å anvende konstitusjonen i den grad sakene han eller hun skal avgjøre, tilsier at grunnloven må anvendes som positiv rett. Likevel har ingen kommet på å karakterisere ting- eller

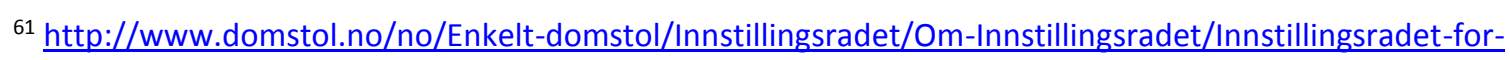
dommere/, jf. domstolloven $\S 55$ a.
} 
lagmannsrettene som «konstitusjonsdomstoler». Høyesteretts eneste særtrekk i denne sammenheng er jo posisjonen som siste instans.

Det forhold at saker der grunnlovsspørsmålet kan by på tvil, stort sett blir innbragt for Høyesterett gjennom anke, innebærer at systemer for sentralisert domstolskontroll i praksis skiller seg noe mindre fra systemer der enhver dommer kan avgjøre konstitusjonelle spørsmål som kommer opp («diffus» kontroll), enn utgangspunktet isolert sett kunne tyde på. Men på andre viktige punkter vil ulikheten mellom de to systemene likevel bestå. Dette gjelder ikke minst skillet mellom abstrakt og konkret kontroll (se nærmere ovenfor, derunder den relevante del av kritikken mot den nye $\S 89$ i grunnloven).

Også det nært relaterte skillet mellom forhåndskontroll (ex ante) og kontroll med om loven har vært anvendt på en måte som er grunnlovsstridig (kontroll ex post), er viktig for å forstå ulikheten mellom systemene. At det norske hører hjemme i sistnevnte gruppe, byr ikke på tvil (se ovenfor). Tendensen til å utforme svært generell domspremisser og til å legge stor vekt på dem, åpner for en viss oppmykning i praksis - men forsterker samtidig behovet for debatt om Høyesteretts sammensetning (se nedenfor).

Det samme gjelder det grunnleggende skillet mellom systemer der avgjørelsene har formelle rettsvirkninger overfor alle (erga omnes) og der de bare gjelder inter partes, slik som her. Den førstnevnte løsningen, som dominerer i systemer med særlige konstitusjonsdomstoler, innebærer i bunn og grunn at domstolen er (med)lovgiver ikke bare reelt, men også formelt; derfor blir avgjørelsene typisk publisert i det som tilsvarer vårt Lovtidend. Selv om den norske staten i praksis alltid trekker de nødvendige, generelle konsekvenser av rettskraftige dommer, er ikke rollen som presedensdomstol tilstrekkelig til å bygge bro over kløften mellom dommer som avgjør enkeltsaker og dommer som også formelt fungerer som (i alle fall) negativ lovgivning, dvs. avgjørelser som sier hva den lovgivende makten ikke kan gjøre.

\section{Avslutning: Noen normative betraktninger}

Det er gode grunner til ikke å bruke fagtermer på en helt annen måtte enn den etablerte, slik Bårdsen (og andre) foreslår her. Men den viktigste grunnen til å feste oppmerksomheten ved 
den nye tendensen til å karakterisere Norges høyesterett som konstitusjonsdomstol, er ikke ordvalget i og for seg, men å belyse de bakenforliggende realiteter.

Hovedmålet med å opprette særskilte konstitusjonsdomstoler er å sikre at medlemmene som kollegium har god innsikt i konstitusjonelle og dermed - i vid forstand - politiske spørsmål. Dette handler ikke bare om faglig innsikt, men også om til dels andre kriterier for hvem som bør rekrutteres. I særlig grad gjelder det behovet for større politisk legitimitet som aktør i det (i vid forstand) politiske liv enn det er sannsynlig at dommere rekruttert ut fra teknisk-juridiske kriterier alene vil nyte godt av.

Behovet for dommere med god innsikt i konstitusjonelle spørsmål blir typisk ivaretatt gjennom ulike former for åpent politisk oppnevning av dommerne (eller av en viktig andel av dem). Dette kjenner vi for så vidt igjen også fra Washington D.C., som det så ofte vises til i norsk debatt. Men til forskjell fra USAs føderale høyesterett er det politiske innslaget i oppnevningen til konstitusjonsdomstolene, og dermed deres sammensetning over tid, tilnærmet uavhengig av dommernes livslengde og andre utenforliggende forhold. I stedet vil sammensetningen av slike spesialinstanser typisk være balansert ved at oppnevning eller forslagsrett er delt mellom posisjon og opposisjon i parlamentet eller mellom organer med potensielt ulik politisk farge. Til dette kommer typisk rullerende oppnevning (for eksempel hvert tredje år) og tidsbegrensede mandater (for eksempel ni eller 12 år) som ikke kan fornyes. Dermed skifter domstolens sammensetning over tid på en slik måte at en viss politisk balanse kan bevares.

I Norge er det vanlig å fnyse av selv svært moderate forslag om åpent politiske elementer. ${ }^{62}$ Et hovedargument vil som regel være at politiske innslag i rekrutteringsprosessen vil svekke domstolens uavhengighet. Men hvorfor skulle uavhengigheten bli svakere av at for eksempel Stortinget ble rådspurt enn ved andre former for rekruttering? Ikke engang eksemplet fra USA antyder noe slikt: Medlemmene av denne «komitéen av ni jurister» i marmortemplet på Capitol Hill føler seg - og opptrer - mer uavhengig enn de fleste. I konstitusjonsdomstoler i Europa må frykten for avhengighet veies mot den politiske balansen i dommerkollegiet.

\footnotetext{
${ }^{62}$ Se for eksempel Arne Fliflet, «Dommernes uavhengighet vil svekkes om Stortinget trekkes inn i en forhåndskontroll med dommerutnevnelsene», Lov og rett, 2016 s. 127-128. DOI: http://dx.doi.org/10.18261/issn.1504-3061-2016-03-01
} 
Det er heller ikke slik at åpent politiske innslag i oppnevningen fører til at avgjørelsene bygger på «partipolitisk argumentasjon». Dette trer med stor tydelighet frem av komparativ erfaring: Medlemmene av velfungerende konstitusjonsdomstoler (som det er mange av) har meget vel forstått at om det er noe de ikke skal gjøre hvis de ønsker å sikre sin legitimitet, er å argumentere «partipolitisk». I mindre veletablerte demokratier lar det seg kanskje finne eksempler på domstoler som avviker fra dette. Men i slike land er det ikke bare medlemmer av særdomstolen for konstitusjonelle spørsmål som kan tenkes å spille et (parti)politisk spill.

Et svært representativt eksempel på at troen på det motsatte har kommet til uttrykk i Norge, finnes i rapporten fra den bredt sammensatte norske Domstolkommisjonen. Den anså det «risikofylt å innføre en utnevnelsesordning som i praksis kan åpne for partipolitiske vurderinger, når man ikke samtidig aksepterer at hensyn av partipolitisk karakter kan trekkes inn i domstolenes dømmende virksomhet». ${ }^{63}$ Slik skriver bare den som ikke har nærmere kjennskap til konstitusjonsdomstoler som viktig institusjon i mange demokratiske stater i vår egen tid.

Det bør også kort nevnes at særskilte konstitusjonsdomstoler slett ikke alltid har svakere omdømme enn for eksempel ordinære høyesteretter i og utenfor Norden. Her er det tilstrekkelig å vise til Tysklands Bunderverfassungsgericht, som scorer høyt på alle skalaer for tillit til offentlige myndigheter.

Hvilken interesse har slike forhold for diskusjonen om vår egen høyesterett? Det er neppe noen annen høyesterett i Europa som på tilsvarende vis samler aktiv domstolskontroll med lover og annen judisiell virksomhet i hendene til jurister oppnevnt etter teknisk-juridiske kriterier alene. ${ }^{64}$ Den norske debatten viser ofte til USAs føderale høyesterett; men der er jo rekrutteringen i høyeste grad politisk, men uten slike balanserende elementer som vi finner i typiske konstitusjonsdomstoler. Ellers i Europa er alle domstoler som utøver aktiv kontroll med lover (og en rekke andre oppgaver av konstitusjonell karakter), spesialiserte og helt eller delvis åpent politisk sammensatt (se ovenfor). Dette står i kontrast til den apolitiske jakten på «den beste» til ledige dommerembeter som nå dominerer tenkningen i Norge.

\footnotetext{
${ }^{63}$ NOU 1999: 19 Domstolene i samfunnet pkt. 7.5.2.

${ }^{64}$ Andre domstoler som eventuelt kunne vært diskutert nærmere i et slikt lys, er høyesterettene i Eire og Island. Den britiske Supreme Court har stor innflytelse, men ikke på vegne av en moderne, skriftlig konstitusjon med formell status over the Queen in Parliament som lovgivende makt, slik som i nesten alle andre land.
} 
Høyesteretts særstilling finnes allerede i dag. Den «politiske» karakteren av domstolens virksomhet vil bli ytterligere aksentuert om slike tendenser i Høyesteretts praksis som er skissert ovenfor, vedvarer eller endog forsterker seg, for eksempel i en slik retning som Arnfinn Bårdsen og enkelte andre slår til lyd for.

Dermed blir det stadig vanskeligere å forstå hvorfor kunnskap om søkernes politiske syn (eller «samfunnssyn»), ikke minst synet på Høyesteretts «rettsutviklende» og dermed rettsskapende funksjon, skulle være irrelevant ved besettelsen av dommerembeter. Hvorfor ville et innslag av balansert politisk rekruttering være så avskyelig at tanken ikke engang fortjener nærmere vurdering?

Eller sagt på en annen måte: Hvorfor skal den høyeste domstolen i akkurat Norge «slippe unna» med en rent faglig-juridisk profil i en tid da stadig sterkere elementer av praktisk og rettspolitisk art gjør sammenligning med egentlige konstitusjonsdomstoler mer berettiget enn før? Det er vanskelig å se at de som faktisk - men altså noe overilt - slår til lyd for å betrakte $\mathrm{H} \varnothing$ yesterett som en «konstitusjonsdomstol», gir noe tilfredsstillende svar på et slikt spørsmål - enn si noe svar overhodet. 